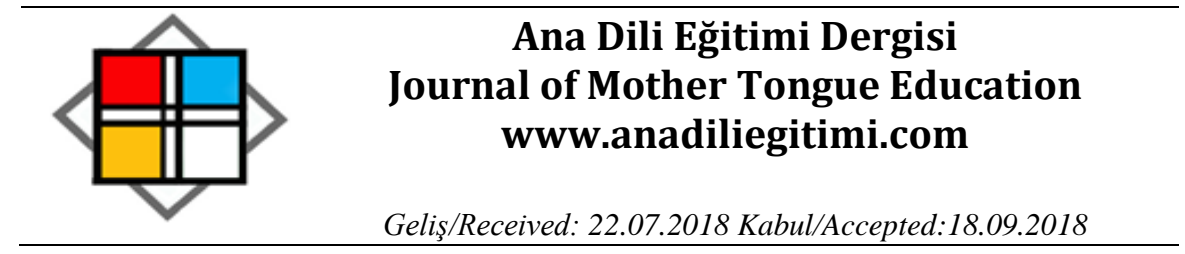

\title{
Türk Edebiyatı Öğretiminde Edebiyat Bakalorya Kitapları
}

\author{
Mehmet Can DOĞAN*
}

Öz

Sözlü ve yazılı sınavlar, öğretimde ölçme ve değerlendirmenin araçlarındandır. Sınavların içeriğini, müfredatta belirlenen konular oluşturur. Bu konular doğrultusunda yazılmış ders kitapları, öğrencilerin öğrenme sürecindeki temel kaynaklarındandır. Aynı zamanda bu kitaplar, sınavlarda sorulan soruların hem bilgisini içerir hem de çerçevesini belirler. Bununla birlikte, öğrencilere sınavlarda yardımcı olmak üzere yazıımış kitaplar da vardır. Ders kitapları, temel kaynak; diğerleri, yardımcı kaynaktır. 1930'lu yılların ilk yarısında basılmış olan "edebiyat bakalorya kitapları", hem dönemin edebiyat öğretimini ve ölçme değerlendirme sistemini yansıtmaları hem de yardımcı kaynak olarak belirginleşmeleri bakımından dikkat çekicidir. Ayrıca bu kitapların edebiyat el kitabı gibi tasarlanması da onları önemli kılmaktadır. Bu makalede, önce 1930'lu yıllardaki edebiyat öğretiminin çerçevesini belirleyen gelişmeler hakkında bilgi verilecek; ardından da anılan yıllarda yayımlanmış ve bugüne kadar üzerinde durulmamış "edebiyat bakalorya kitapları", Türk edebiyatı öğretimindeki rolleri yönünden değerlendirilecektir. Değerlendirmede kitapların hazırlanış yöntemi, içeriği ve yazarlarının tutumuna yoğunlaşılacaktır.

Anahtar Kelimeler: Türk edebiyatı öğretimi, edebiyat bakalorya kitapları, Muvaffak Hüsnü Benderli, Sadeddin Nüzhet Ergun, Yusuf Ziya Ortaç

\section{Literary Baccalaureate Books in Teaching Turkish Literature}

\begin{abstract}
Oral and written exams are tools of assessment and evaluation in teaching. The content of the exams is defined in the curriculum. Textbooks written in line with these subjects are the primary sources of learning process of students. These books contain both information and the frame of the questions asked in the exams. However, there are some other printed references to prepare students for the exams, that is supplementary sources. The 'literary baccalaureate books' published in the first half of the 1930s are striking in terms of both reflecting the period's literary teaching and assessment system and becoming a reference or a supplementary book. Moreover, these books were designed as literary handbooks, which also makes them important. This article will firstly give some information about the development that defines the frame of literature teaching in the 1930s, and then the 'literary baccalaureate books' which were published in the mentioned years and which have not been examined so far will be evaluated in terms of their role in the teaching Turkish literature. The evaluation part will focus on the method and content of the books and the attitude of the authors as well.
\end{abstract}

Keywords: Teaching Turkish literature, literary baccalaureate books, Muvaffak Hüsnü Benderli, Sadeddin Nüzhet Ergun, Yusuf Ziya Ortaç

\footnotetext{
* Doç. Dr., Gazi Üniversitesi İletişim Fakültesi Gazetecilik Bölümü, Ankara, mehmetcandogan@yahoo.com
} 


\section{Giriş}

Cumhuriyet Dönemi'nde dil ve edebiyat öğretimi, 3 Mart 1924'te çıkarılan “Tevhid-i Tedrisat Kanunu"nun belirlediği çerçevede biçimlenir. Bu kanunla eğitim ve öğretim laik bir mahiyet alır ve eğitim birliği sağlanır. Yücel (1938: 15)'e göre, “Cumhuriyet maarifini ilk kuran kanun, tevhidi tedrisat kanunudur". Ortaöğretim kurumlarının müfredatı, bu kanun sonrasında 1924'te düzenlenir.

1340 (1924)'ta yayımlanan Lise Müfredat Programlarının Esbâb-ı Mûcibe Lâyihası adlı kitabın "Türkçe Programının Esbâb-ı Mûcibesi” başlıklı bölümünde, Türkçe ve edebiyat derslerinin içeriği ortak olarak belirlenmiştir. Lise adı altında toplanan ortaöğretimin ilk üç yılı ortaokul, sonraki üç yılı ise lise dönemini kapsamaktadır. Mehmet Fuad (Köprülü), Ali Canip (Yöntem) ve Süleyman Şevket (Tanlı) tarafından hazırlanan içerikte, öncelik "kıraat"e (okumaya) verilir; "kıraat"in önemine dikkat çekilerek, liselerin her sınıfında dil ve sanat eğitimini kıraat merkezinde toplamak gerektiği vurgulanır. "Kıraat"in ardından "Inşad” dersinin nasıl işleneceği ve öğrenciye kazandıracağı davranışlar açıklandıktan sonra, "Imlâ" ve "Tahrir" (yazma) dersleri üzerinde durulur. Programa (1340a: 45) göre, "Tahrir mevzuları hayattaki ihtiyaçlara tekâbül etmelidir". Edebî bilgiler konusu, "kıraat" ile birlikte değerlendirilir ve edebî bilgiler öğretiminin merkezine çeşitli edebî metinlerin okunması ve çözümlenmesi konulur. Böylece hem bilginin metin üzerinden kazanılması hem de öğrencinin yazıda buluş, düzen, birlik, açıklık, doğalık gibi özellikleri uygulamaya aktarması amaçlanır. Yazı türlerinin de metinler üzerinden somutlaştırılarak öğretilmesi benimsenir. Edebiyat tarihinin okumaya hazırlığın son aşaması olduğu ve "eski edebiyatla beraber yeni sanatın müspet ve maddî malumatı ikmal olunarak" verilmesi gerektiği vurgulanır. Bunun için de hem Doğu edebiyatının özellikleri hem de Batı edebiyatına ait yazı türlerinin öğretilmesi gerektiği belirtilir. Uygulama, "Bu türlü edebî malumat, muharrirler hakkında verilecek izahatla beraber kıraat parçaları etrafına toplanır" (1340a: 47) sözüyle açıklanır. Liselerde "insanî" (hümanist) öğretim vermek amacıyla Avrupa kültürünün temelini oluşturan Yunan ve Latin birikimine dikkat çekilir ve yazı türleri öğretilirken Avrupa edebiyatlarından örnekler verilmesi gerektiği belirtilir. "Türk Edebiyatı Tarihi”nin liselerin son iki sınıfında öğretilmesi; bunun yanı sıra metin tahlili ile Batı edebiyatının bazı büyük yazarlarının hayat ve eserleri hakkında bilgi verilmesi de kabul edilir.

Türkçe programı hazırlanırken gözetilen noktalar hakkındaki açıklamalar, 1340'ta yayımlanan Lise Birinci Devre Müfredat Programı ve Liselerin Ikinci Devre Müfredat Programı'na ilişkindir. "Liseler" sözüyle ortaokul ve lisenin kastedildiği programlar, ortaöğretimin üçer yıllık iki bölüme ayrıldığını göstermektedir. Bu programlardan ilki, ortaokullar; ikincisi, liseler için hazırlanmıştır. Söz konusu programların ilkinde, haftada yedi saat okutulan "Türkçe" derslerinin içeriği "Kıraat" (2 saat), "Inşad" (1 saat), "Sarf ve Nahiv" (2 saat), "İmlâ" (1 saat) ve "Kitâbet" (1 saat) olarak belirlenmiştir (1340b: 5, 9). Liselerin ikinci Devre Müfredat Programı'ndaki "Türkçe ve Edebiyat" dersinde ise üç sınıf için konular ayrımıştır. Buna göre, liselerin dördüncü sınıfında "Türk Lisan ve Edebiyatı" (3 saat), beşinci sınıfında 


\section{Türk Edebiyatı Öğretiminde Edebiyat Bakalorya Kitapları}

"Türk Edebiyatı Tarihi” (3 saat) ve altıncı sınıfında "Garp Edebiyatı Dairesinde Türk Edebiyatı" (2 saat) konuları işlenecektir. Programda her bir konunun içeriği de ayrıntılı olarak açıklanmıştır. Hem Türk edebiyatı ders kitaplarının hem de bizim bu çalışmamızın konusunu oluşturan "edebiyat bakalorya kitapları"nın içeriğini belirlemesi bakımından önemli görünen bu içerik şöyledir:

\section{"Türk Lisan ve Edebiyatı}

Bilhassa kıraate müsteniden şu edebî malumat gösterilecektir.

Nesir ve nazım, vezinler, kafiyeler, eski divan edebiyatında nazım şekilleri, mısra, beyit, gazel, kaside, kıt'a, mesnevi, rubâi, murabba, muhammes, müseddes, terci-i bent, terkib-i bent, terbî', tahmis, tesdis, taştir, müstezat, tarih, divan, hamse, eski nesir, millî vezin ve millî edebiyat şekilleri: koşma, destan, türkü, tuyuğ, ilh...

Teşbih, istiare, mecaz-ı mürsel, kinaye.

Manaya ait sanatlar: teşhis ve intak, tenasüp (mirâ'ât-i nazîr), rücu, leff ü neşr, hüsn-i talil, mübalağa, tecâhül-i ârif ve emsali.

Lafza ait sanatlar: cinas, seci, tazmin, iktibas ve emsali.

Eski divan edebiyatı vasıfları. Siyasî Tanzimat’ı müteakip başlayan yeni edebiyatta nesir ve nazmın nevileri.

\section{Türk Edebiyatı Tarihi}

İslamiyet'ten Evvel Türk Edebiyatı

Kable'l-İslam Türk tarih ve medeniyetine umumi bir nazar - Lisan ve yazı: eski Türk lehçeleri, Yeniseyi ve Orhun Kitabeleri, Orhun yazısı, Uygur yazısı, Türkçede kullanılan sair muhtelif elifbâlar Millî Türk destanı: Oğuz, Tukyu ve Uygur destanları - İlk şiirler ve ilk şairler: âyinlerde şiir, millî musiki, ilk mevzular, vezin ve kafiye, eski Türk edebiyatına umumi bir nazar.

İslam Medeniyeti Dairesinde Türk Edebiyatı

İslam medeniyeti ve Türkler - İslamî edebiyat: Arap ve Acem edebiyatlarının tarihî inkişafına bir nazar - İslamî edebiyatta tasavvuf tesirâtı ve mahiyeti - İslamî edebiyatta vezin ve şekil.

Moğol istilasına kadar Türk edebiyatı: Karahanîler devrinde Türk lisan ve edebiyatı: Kutadgubilig - Selçukîler devrinde Türk lisan ve edebiyatı - tasavvuf edebiyatının menşei ve inkişafı, Ahmed Yesevî ve muakkipleri - Harzem ve Anadolu'da Tük edebiyatı.

Moğol istilası ve neticeleri - Moğol istilasından sonra Türk lehçeleri: Çağatay lehçesi, Oğuz lehçesi, Oğuz lehçesinin Şarkî ve Garbî iki şubeye ayrılması. 
Timur istilasına kadar Türk edebiyatı: Bu devre kadar Çağatay edebiyatının geçirdiği devreler ve bu edebiyatın büyük şahsiyetleri - Anadolu (Garp Türkleri) edebiyatının geçirdiği devreler ve büyük şahsiyetleri [şairler, nasirler, sûfîler, mütercimler, halk şairleri ve hikâyecileri]. Âzerî (Şarkî Oğuz) edebiyatının tesis ve inkişafı.

Onuncu asra kadar Türk edebiyatı: Çağatay, Osmanlı, Âzerî edebiyatlarının bu asra kadar geçirdiği devreler ve büyük şahsiyetleri.

Altıncı Sınıf: Üçüncü asırdan Türklerin Garp medeniyeti dairesine girmesine kadar Türk edebiyatı: Çağatay, Osmanlı, Âzerî edebiyatlarının tekâmülü (Onuncu sınıfta takip edilen usul dairesinde devam olunacaktır.).

\section{Garp Medeniyeti Dairesinde Türk Edebiyatı}

Tanzimat devrinde Türk edebiyatı: yeni edebî nevilerin zuhur ve inkişafı ve teceddüt edebiyatının başlıca mümessilleri, eski edebiyatın son mümessilleri, edebiyat ve inkılâp - edebiyatta teceddüt ve irtica mücadelesi - Servet-i Fünûn zümresi ve muakkipleri - Millî Edebiyat cereyanı, esbâb ve avâmili ve başlıca mümessilleri - Türk edebiyatının diğer şubeleri: Garp medeniyeti altında Âzerbaycan, Kırım, Kazan, Türkistan sahalarında Türk lisan ve edebiyatının tekâmülü." (1340c: 4, 8)

Türkçe ve Edebiyat dersi müfredat programını hazırlayanlardan biri olan Ali Canip, 1340'ta "liselerin ikinci devresinin birinci sınıfına mahsus" olmak üzere ilk edebiyat ders kitabını hazırlar. Kitabın çıktığı yıl, "Orta Dârü'I-Muallimîn Edebiyat Tarihi Muallimi” olan yazarın Edebiyat (Ali Canip, 1340) adlı kitabı, Türkiye Cumhuriyeti Maarif Vekâleti Neşriyatı tarafından yayımlanır. Kitap, yukarıda "Türk Lisan ve Edebiyatı" başlığı altında aktarılan konuları içermektedir.

1924'te hazırlanan müfredat programı, 1927' de küçük bazı değişikliklerle yenilenir. 1340 Tarihli Ortamektep ve Lise Müfredat Programlarına Zeyl adlı kitapçıkta bu değişiklikler ilan edilir. "Edebiyat Tarihindeki Tadilatın Esası" başlığı altındaki açıklamada, lise birinci sınıftaki üç saatlik "Türkçe ve Edebiyat" dersinin bir saatinin kıraate; ikinci sınıfta da aynı dersin bir saatinin "izahlı edebî kıraat"e, bir saatinin de "tedkik ve tahrire" ayrıldığı bildirilir (Kurul, 1927). Bu tadilat, programın içeriğine ilişkin bir düzenlemeyi değil, dersin uygulanmasına ilişkin bir değişikliği haber verir.

Ali Canip, 1927 'de yazıp dönemin dergilerinde yayımladığı yazılarla "Türkçe ve Edebiyat" dersi müfredatını eleştirir. Bu yazılar, Hıfzı Tevfik (Gönensay) ve Köprülüzâde Mehmed Fuad (Köprülü)'ın tepkisini çeker. Ali Canip, dersin içeriğinin millî bir devlet olan Türkiye Cumhuriyeti'nin ideallerini yansıtmadığını ve öğrencilere edebî zevk vermediğini belirtir. Yazar, edebiyat tarihi yerine Cumhuriyet'in ideallerini benimsemiş yazarların metinleriyle öğrencilere edebiyat zevki verilmesi 
gerektiğini savunur. Hıfzı Tevfik ile Köprülüzâde Mehmed Fuad ise mevcut programın doğru ve yeterli olduğunu ileri sürerek Ali Canip’e karşı çıkar (Ogur, 2009).

3 Kasım 1928'de Resmî Gazete' de yayımlanarak yürürlüğe giren “Türk harflerinin kabul ve tatbiki hakkında kanun"la birlikte bütün ders kitapları Latin alfabesiyle yeniden yayımlanır. 1929'da Türkçe ve edebiyat derslerinin programları da yeniden düzenlenir. Bu düzenlemede, önceki programdaki edebî bilgiler ile edebiyat tarihine ilişkin konular kaldırılmaz ama konuların Cumhuriyet'in ideallerini yansıtacak metinlerle desteklenerek anlatılması ve edebiyat tarihine daha az yer verilmesi benimsenir. 1935'te bazı dersler için kılavuzlar hazırlanırken edebiyat dersinin içeriğine ilişkin olarak da düzenlemeye gidilmesi üzerinde durulur. Hasan Âli Yücel ve Falih Rıfkı Atay başkanlığında oluşturulan iki kurul, edebiyat programları ile edebiyat kitaplarını inceler. Sonuçta, edebiyat kitaplarının değiştirilmemesi ama derslerin işlenişinde yeni bir yöntem geliştirilmesi benimsenir. Buna göre, "aruz tanıtılacak, ama kalıplar okutulmayacak. Teşbih, istiareden başka anlam sanatları gösterilmeyecek. Divan edebiyatı genel nitelikleriyle tanıtılacak; birinci derece kişilerden, dili sade metinler seçilerek okutulacak, öğrenciler kullanılmayan yabancı kelimelerle, tamlamalardan sorumlu tutulmayacaktı[r]" (Göğüş, 1970: 150).

\section{Edebiyat Bakalorya Kitapları}

Yukarıda anlatılan süreç, Erken Cumhuriyet Dönemi'nde Türkçe ve edebiyat derslerinin sadece birer ders olarak değil, aynı zamanda Cumhuriyet rejiminin beklentilerini temsil eden birer alan olarak düşünüldüğünü de göstermektedir. Hem derslerin müfredatının oluşturulması hem bu müfredat doğrultusunda ders kitaplarının ve yardımcı kaynakların hazırlanması hem de derslerin işlenmesinde Cumhuriyetçi ve laik bir bilinç kazandırma hedeflenmiştir. Sınavlar, dersler için ölçme ve değerlendirme aracı olduğu kadar bu bilincin kazandırılıp kazandırımadığını da yansıtan bir araç olarak işlev görmüştür. 1930'lu yılların ilk yarısında Kimya, Coğrafya, Tarih dersleri için olduğu gibi Edebiyat dersi için de hazırlanan bakalorya kitapları, rejimin beklentilerini pekiştiren yayınlar olarak belirmiştir.

Bakalorya, "Lise mezunu sayılabilmek için 1926-1935 yılları arasında uygulanan Üniversiteye girme hakkını veren ve Lisenin tüm sınıflarının konularını kapsayan yazılı ve sözlü sınav"dır (Akyüz, 2010: 486). Edebiyat bakalorya kitapları, diğerlerinde olduğu gibi, lisenin tüm sınıflarındaki edebiyat dersi müfredatına göre hazırlanmıştır. Bunlar, birinin adında da işaret edildiği üzere, "el kitabı" olarak düzenlenmiş ve kitaplarda, konular, özet olarak anlatılmıştır.

1933-1935 yılları arasında, adında "bakalorya" sözcüğü bulunan üç kitap yayımlanmıştır. Bunlar; Muvaffak Hüsnü (Benderli)'nün Edebiyat Bakalorya Elkitabı, Sadeddin Nüzhet Ergun'un Edebiyat ve Edebiyat Tarihi Özü - Liseler İçin Edebiyat Bakalorya Kitabı ve Yusuf Ziya (Ortaç)'nın Edebiyat Bakalorya Kitabı'dır. Her kitap, edebiyat dersi müfredatına bağlı kalmakla birlikte, yöntem, 
yaklaşım ve anlatım yönünden diğerinden farklılık göstermektedir. Bu nedenle her birinin ayrı ayrı değerlendirilmesi gerekir.

\section{Edebiyat Bakalorya Elkitabı}

İstanbul Erkek ve Fevziye Liselerinde Türkçe ve Edebiyat Muallimi olan Muvaffak Hüsnü’nün Edebiyat Bakalorya Elkitabı (1933) adlı çalışması, "Lise I. II. III. Hülâsaları" açıklamasıyla sunulmuştur. Yazar, "Bir ỉki Söz" başlıklı sunuş yazısında, kitabın "yeniden öğretmekten ziyade, hatırlatmak için" yazııdığını ve bakaloryaya girecek öğrencilere edebiyat el kitabı olarak düzenlendiğini belirtir. Ayrıca bu kitabın Süleyman Şevket, Ali Canip, Agâh Sırrı, İbrahim Necmi, Sadeddin Nüzhet ve Mustafa Nihat'ın kitaplarından çıkarılan özetlerle oluşturulduğunu açıklar (Muvaffak Hüsnü, 1933). Bu kitaba, bir Türkçe ve edebiyat öğretmeninin aldığı ders notları denebilir.

Edebiyat Bakalorya Elkitabı'nın içeriğini, yukarıda anılan adların çalışmaları; yaklaşımı da özellikle Ali Canip'in Edebiyat adlı kitabı belirler. Edebiyat'ın Latin harfleriyle ilk baskısı, 1929 yılında, Maarif Vekâleti Millî Talim ve Terbiye Dairesi tarafından ders kitabı olarak yayımlanmıştır. Ali Canip, 1927 'de edebiyat müfredatına getirdiği eleştirileri yansıttığı kitabını, edebiyat öğretiminin öğrenciye edebî zevk kazandırması hassasiyetiyle düzenlemiş ve konuları, Cumhuriyet'in ideallerini yansıtan metinler üzerinden anlatmıştır. Lise birinci sınıf için hazırlanan kitapta, yazarın Osmanlı edebiyatına mesafeli duruşu rahatlıkla fark edilir. Örneğin "lafza ait sanatlar"ı anlatırken bunların "lâfız oyuncă̆ı" olduğunu vurgular ve "artık edebiyatımızda lâfız oyuncakçılığına iltifat eden yoktur" (Ali Canip, 1929: 91) der; Türk edebiyatı Avrupalılaştıkça lafza ait sanatların yavaş yavaş ortadan kalktığını ileri sürer. Cumhuriyet'in idealleri doğrultusunda bir edebiyat kanonu yaratma niyeti taşıyan Ali Canip, hem Osmanlı edebiyatını hem de Servet-i Fünûn Edebiyatı'nı, milliyetçi duygu ve düşünceden uzak bulur. Bu edebiyatları, "zümre edebiyatı" olarak değerlendiren yazar, yeni edebiyatın onların yolundan gitmediğini ve gençlerin de bu söyleme iltifat etmediğini ısrarla vurgular (Ali Canip, 1929).

Muvaffak Hüsnü, Ali Canip'in tutumunu benimsediği gibi, onun bazı yargılarını da kitabına olduğu gibi aktarmıştır. "Divan edebiyatında bugün kıymeti hiç kalmayan bazı oyuncaklar vardı" (Muvaffak Hüsnü, 1933: 22) sözü, edebiyat retoriğinin ideolojik yaklaşım tarafından zedelendiğinin işareti olarak anılabilir. Divan ve Tasavvuf şiirinin "fena yol" olarak kabul edilmesinde de söylem belirleyicidir. "Hitabet nevi"ni tanıtırken yapılan şu yorum da ideolojik tutumu yansıtır: "Hitabet hürriyetin olduğu yerde doğar ve yaşar. Bu imkânı asırlarca bulamayan Osmanlı Türklerinde, hitabetin inkişafını beklemek doğru olmaz." (Muvaffak Hüsnü, 1933: 33) Yazar, hitabetin gelişiminde, Cumhuriyet'le birlikte camilerde Türkçe hutbe verilmesinin ve Halkevlerinin çabalarının önemli olduğunu belirtir. 
Muvaffak Hüsnü, bazı yargılarında özneldir. Bu yaklaşım, "Küçük hikâye tarzı, bugün tamamı ile sahipsizdir. Ercüment Ekrem Bey de artık yazmıyor." (Muvaffak Hüsnü, 1933: 29) ve "[Fitnat Hanım] biraz daha kadın olsaydı, muhakkak ki edebiyatımızın mühim bir siması olacaktı." (Muvaffak Hüsnü, 1933: 85) cümlelerinde olduğu gibi, söyleyişe de yansır. Ali Canip'in edebiyat kanonu için ölçüt ve değer olarak öne çıkardığı Abdülhak Hâmid'i, Muvaffak Hüsnü de aynı şekilde sunar; Tevfik Fikret'i de kanonun değerlerinden bir şair olarak belirginleştirir. Yeni edebiyat kanonu, kaynak olarak halk edebiyatını öne çıkarır. Bu, Ali Canip tarafından ısrarla vurgulanmış bir görüştür ve Muvaffak Hüsnü de bu görüşü sahiplenir. Aynı tutum, Osmanlı ve Tasavvuf edebiyatlarının "zümre edebiyatı" olarak benimsenmesini de hazırlamıştır.

Muvaffak Hüsnü, "O edebiyatımızın hassas bir sanatkârı kudretli bir simasıdır." (Muvaffak Hüsnü, 1933: 72) ve "Temiz ve özlü şiirleri vardır." cümlelerindeki gibi, kalıplaşmış sözlerle değer bildirmeyen yargılarda bulunur. Bazı şair veya yazarların etnik kökenini öne çıkararak, yargısını bu durum üzerinden geliştirir. Taşlıcalı Yahya Bey için söylenen "Türklük ve Türkçeye karşı iyi duyguları olmayan bu adam, Arnavutlukla övünmüştür." (Muvaffak Hüsnü, 1933: 75) sözü, bu bağlamda anılabilir.

Muvaffak Hüsnü, bakaloryaya girecek öğrenciler için hazırladığı elkitabında temel bilgileri çok kısa olarak aktarma çabasındadır. Türk edebiyatı birikimini ideolojik bir yaklaşımla Türkçe ve milliyetçilik süzgecinden geçiren yazar, özellikle divan ve tasavvuf edebiyatıyla ilgili bilgi verdiği bölümlerde Sadeddin Nüzhet'in Tanzimat'a Kadar Muhtasar Türk Edebiyatı Tarihi ve Nümuneleri (1931) adlı kitabından kaynak belirtmeden alıntılar yapar.

Muvaffak Hüsnü, sınava hazırlık kitabı olan Edebiyat Bakalorya Elkitabı'nı, "acele" hazırladığını belirtir. Bu açıklama, mevcut ders kitapları ve yardımcı ders kitaplarından alınan bilgilerle kotarılan kitabı, ticarî kaygının yönlendirdiğini düşündürmektedir. Bu durumu, kitabın sonraki baskısı da doğrular. Muvaffak Hüsnü Benderli, “Garp Edebiyatı” başlıklı bir bölüm de eklediği kitabını, 1937'de Edebiyat ve Edebiyat Tarihi El Kitabı adıyla yeniden yayımlamıştır. Bu baskıyı, sınavın adııın değişmesi de yönlendirmiştir. "Olgunluk sınavları için lise I. II. III." açıklaması, bu yönlendirenin göstergesidir.

\section{Edebiyat ve Edebiyat Tarihi Özü}

Sadeddin Nüzhet Ergun'un Edebiyat ve Edebiyat Tarihi Özü adlı kitabı, ilk sayfasında, Liseler İçin Edebiyat Bakalorya Kitabı diye sunulmuştur. Kitabın kapağında, "Lise ikinci devre olgunluk imtihanına girecekler için yardımcı kitap" açıklaması yer almaktadır. Yayın tarihi; kapağında 1935; ilk sayfasında 1934 olarak belirtilen kitabın bakalorya için hazırlandığı bellidir. Ama 1935'ten itibaren bakalorya sözcüğü yerine olgunluk sınavı sözü kullanılmıştır. Bu yüzden 1934'te "bakalorya” için hazırlanan kitabın 1935'te "olgunluk" sınavına gireceklere kaynak olarak sunulduğu anlaşılır. 
Edebiyat ve Edebiyat Tarihi Özü'nün adındaki “öz" sözcüğü, onun lisenin üç sınıfında görülen edebiyat derslerindeki konuların özetini içerdiğini bildirir. Yukarıda değinildiği gibi, Sadeddin Nüzhet, 1931'de Tanzimat'a Kadar Muhtasar Türk Edebiyatı Tarihi ve Nümuneleri adlı bir kitap çıkarmıştır. Adında "ders kitabı" ibaresi bulunmamakla birlikte bu kitap, lise ikinci sınıf müfredat programına göre hazırlanmış bir ders kitabıdır. Bugün bakıldığında lise ikinci sınıf için hayli ayrıntılı ve ağır bir içerik sergilediği görülen bu kitap, referans değerindedir. Yazar, Edebiyat ve Edebiyat Tarihi Özü'nün ikinci bölümünde, bu kitabındaki bilgileri özetleyerek kullanmıştır. Kitabın beşte birini kaplayan ilk bölümü, bir hayli yüzeyseldir. Ergun, edebiyat terimlerini tanımlayıp örneklemekle yetinmiştir. Vezin, kafiye, söz ve anlam sanatları ile nazım biçimleri hakkında bilgi verilirken kullanılan örnek metinlerin özgünlüğü dikkati çekmektedir.

Konuların anlatımında nesnel bir yaklaşım sergileyen Sadeddin Nüzhet Ergun, iktidarın söylemini, sadece Gazi Mustafa Kemal'e ve onun Nutuk'una göndermelerde bulunarak paylaşır. Kitabın “Edebiyat Tarihi”ne ayrılan ikinci bölümünde, iktidarın söylemi yer yer belirginleşir. Örneğin “islam'dan önce Tük edebiyatı" anlatılırken bu dönemin Türk toplumunda kadının erkekle eşit olduğu vurgulanır. Üçüncü bölümde "Türkçülüğün İnkişafı" anlatılırken 1934'te yapılan İkinci Türk Dili Kurultayı sonrasındaki "Öz Türkçe" söyleminin, "İşte bu son şuurlu cereyandan sonradır ki özü de sözü de Türk bir edebiyat meydana gelebilecektir." (Ergun, 1935: 183) sözüyle benimsendiği anlaşılır. Bununla birlikte Ergun'un anlatım tonu, Ali Canip ve Muvaffak Hüsnü'nün bastırıcı egemen tonuyla aynı değildir.

Sadeddin Nüzhet Ergun, Ali Canip gibi, Osmanlı ve Tasavvuf edebiyatlarının "güzideler"in edebiyatı olduğunu belirtir ama bunu, ideolojik bir vurgu ile değil, nesnel bir tutumla ifade eder. Ayrıca bu edebiyatlar hakkında bilgi verirken ideolojik bir süzgeç de kullanmaz. Gerçi o da Osmanlı edebiyatında "kelime oyuncakçılığı"ndan söz eder ama bunu, bütünüyle edebiyata mal etmeyip bazı şairlerin tercihi olarak belirginleştirir.

Ergun, yargılarında basmakalıp ifadelerden uzak durur; analitik bir tavır sergiler ve nesnesi ile kendisini ayırma yetkinliği gösterir. Bu bağlamda, "Şiî ve daha kuvvetli bir ihtimal ile Hurufî olan Habibi, edebiyatımızda Nesimi ile Fuzuli arasında bir haddi vasıl addolunabilir." ve "Âşıkane, rindane, arifane manzumeler yazan Naili bazı manzumelerinde de tamamen maddî kalmış, o zamanki hayatın korkunç ve çirkin safhalarını terennüm etmiştir." (Ergun, 1935: 69, 81) cümleleri anılabilir. Yazar, yargılarında bir değer düşüncesi geliştirirken söz konusu şahsiyeti, tarihsellik içinden görür. Bu yönüyle Ergun'un yorumlarında, Fransız tarihçi Hippolyte Taine'in "muhit, ırk, zaman" teorisine bağlı kaldığı söylenebilir. Ergun'un (1935: 97) “Kâtip Çelebi, aynı zamanda bir müteceddittir. Medrese âlimlerinin dar zihniyetlerine hücum eden ve Avrupa'nın o zamanki telakkilerini memlekete getirmek isteyen ilk mütefekkirimiz hiç şüphesiz Kâtip Çelebi olmuştur." yargısı, bu bağlamda anılabilir. 
Edebiyat ve Edebiyat Tarihi Özü, yarısından fazlasını oluşturan “Garp Medeniyeti Tesiri Altında Türk Edebiyatı" başlıklı üçüncü bölümüyle dikkati çeker. Bu bölüm, ilk kez yazılmış olmasıyla Sadeddin Nüzhet Ergun'un eserleri arasında da yeniliği ve özgünlüğüyle öne çıkar. Konuya yaklaşımında nesnel tutumdan ayrılmayan yazar, Tanzimat Edebiyatı'ndan 1930'ların ilk yıllarına gelene kadarki şair ve yazarları, tarihsel bir bakışla değerlendirir. Özellikle yakın döneme ilişkin özgün bilgiler içeren bu bölümde, Servet-i Fünûn Edebiyatı'na mensup şair ve yazarların dilini eleştirirken egemen ideolojinin söylemini kullanır ama buradaki ton, yargılayıcı değil, betimleyicidir.

Sadeddin Nüzhet Ergun'un Edebiyat ve Edebiyat Tarihi Özü adlı bakalorya kitabı, "Türkçe ve Edebiyat" müfredat programındaki konuların işlenmesinde engin bir bilgi ve birikimi yansıtır. Yazar, tutum olarak da nesnelliğiyle öne çıkar. Bununla birlikte, kitap üzerine bir yazı yazan Nahid Sırrı Örik, yazarın özellikle üçüncü bölümdeki yargılarını eleştirir. Kitabın ikinci bölümünde bazı bilgi yanlışları bulunduğunu belirten Örik, bunlara değindikten sonra asıl üçüncü bölümdeki tutuma yoğunlaşır. Yakın dönem şair ve yazarı olarak değerlendirilen adlardan bazılarının kitapta yer almaması gerektiğini ileri süren yazara göre, olması gereken adlardan bazıları da kitapta yoktur. Örik'in andığı adlardan biri dikkat çekicidir. Örik, "150'likler" arasına alındıktan sonra Türkiye'den kaçan Refik Halid Karay'a kitapta yer verilmemesini büyük bir eksiklik olarak anar ve bu tutumundan ötürü Ergun'u kınar (Nahid Sırrı, 1935). Örik'in haklı eleştirisinin muhatabının Ergun değil, egemen ideoloji olduğunu belirtmek gerekir.

Nahid Sırrı Örik'in getirdiği eleştirilerden biri de, Ergun'un şair ve yazarları değerlendirirken önemli ile önemsizi gözetmemiş olmasıdır. Yazar, bazı adların kendilerine ayrılan satırları hak etmediğini; bazılarına da hak ettikleri kadar yer verilmediğini ileri sürer. Örik (1935: 328)'e göre, “Eğer bu kitap lise talebesinin eline verilecekse edebiyatı cedide devrinden bugüne kadarki kısmını yani kitabın hemen yarısını koparıp yırtmaktan başka bir çare ve yol yoktur." Bilgi yanlışlarına ilişkin söyledikleri bir yana, Örik, eleştirilerinde söz konusu kitabın bakalorya (olgunluk) sınavına girecek öğrenciler için hazırlandığını göz ardı etmiş gibidir.

\section{Edebiyat Bakalorya Kitabı}

Yusuf Ziya (Ortaç)'nın Edebiyat Bakalorya Kitabı, "Liselerin ikinci devre talebesi için bakalorya kitabı" olarak sunulmuştur. Kitabın birinci bölümünde, diğer bakalorya kitaplarında olduğu gibi, edebî bilgilere yer verilir. Burada, edebiyat terimlerini somutlaştırmak için seçilen örnekler dikkati çeker. Yusuf Ziya, örneklerini ya edebiyat kanonunun ölçüt ve değer diye öne çıkardığı şairler ya da kendi kuşağındaki hececilerden seçer. Tutum ve anlatım tonu olarak da kanonun tavrını benimseyen yazar, "Osmanlıca” yı, "uydurma bir dil” olarak sunar; aruz ölçüsü için de şunları söyler: "Arap ve Acem diline uygun olan bu vezinler, artık öz ve zengin kaynağına dönen güzel Türkçenin asla nazım ölçüsü olamaz." (Yusuf Ziya, 1935: 6) Yusuf Ziya'ya göre Osmanlı edebiyatı, "medrese tahsili görmüş, zevki, irfanı 
Acemleşmiş bir küçük zümreye hitap et[mektedir]". Özcü bir tutum benimseyen yazar, Türklerin dünyanın "en eski milleti" olduğunu savunur. Kitabın "Edebiyat Tarihi" başlıklı ikinci bölümünde bu tutum daha da belirginleşir. Yazara (1935: 33) göre, "Dünya edebiyatları içinde denilebilir ki Türk edebiyatı kadar geniş ve şümullü bir edebiyat yoktur".

Yusuf Ziya, yargılarında fevridir. Kişisel beğeniyle değerlendirmelerde bulunan yazar, Fuzuli'nin Türk edebiyatının şüphesiz "en kuvvetli lirik şairi", Bâki'nin "usta bir kelime "oyuncakçısı", ifade gücü yönünden Nef'i'nin Türklerin "en büyük şairi" olduğunu, Türklerin Nedim derecesinde "ince ve her dem taze" ikinci bir şair yetiştiremediğini söyler. Kanonun benimsediği adları fevri ve abartılı bir biçimde öne çıkaran yazar, kanonun dışladıklarını da aynı tutumla öteler. Örneğin, Sümbülzâde Vehbi'nin Lûtfiye adlı eserinin "saçma sapan fikirler" içerdiğini belirtir.

Yusuf Ziya, tarihselliği gözetmediği gibi, analitik de değildir. Analitik düşünen ve tarihselliği gözeten Sadeddin Nüzhet'in yenilikle alakası olmadığını söylediği Âkif Paşa'yı eklektik tutumlu Yusuf Ziya, yeniliğin öncülerinden biri olarak sunar. Kimi yargılarında milliyetçilik kabulünün yönlendirmesiyle şahsiyetlerin özel hayatına ve etnik kökenine dikkat çeker. Örneğin, Ahmet Vefik Paşa'nın "titiz bir Türkçü" olduğunu vurgulamak üzere, Paşa'nın evine Avrupa malı sokmadığını ve kendisinin de ailesinin de Türk malından başka elbise giymediğini; Şemsettin Sami'nin etnik olarak Arnavut olmasına rağmen çalışmalarıyla "öz Türk çocuğu" sayılması gerektiğini söyler. Yazarın kimi yargılarını da kuşak çatışmalarından kalan tortular ve kişisel ilişkilerindeki sorunlar belirlemiş gibidir. Şu cümleleri bu bağlamda anılabilir: "Hüseyin Cahit Beyin üslûbundaki sadelik, bir mektepli kaleminin basitliğinden ileri gidemez.”, “[Ali Ekrem] Namık Kemal'in en zayıf eseridir de diyebiliriz.” (Yusuf Ziya, 1935: 139, 144) Bu ve benzeri yargıların Servet-i Fünûn Edebiyatı'na mensup şair ve yazarlara ilişkin oluşu dikkati çekmektedir.

Yusuf Ziya'nın yaklaşımı gibi söyleyişi de sıkıntııdır. Abartılı yargılarını sanatı bir söyleyişle belirginleştirir. "Abdülaziz'in hal'inden sonra, talih ona gülümsedi. Fakat kış güneşi kadar ömürsüz bir tebessümle." ve "[Tevfik Fikret] Meşrutiyet ilan edilince, gökten yere iner gibi yuvasından şehre indi." (Yusuf Ziya, 1935: 118, 131) gibi cümleleri, bu yargıyı örnekler.

Edebiyat Bakalorya Kitabı, öğretici bir metinden çok edebiyat dünyasında yer alan deneyimli bir yazarın kişisel notları olarak belirginleşir. Kişisel ve ideolojik yönlendirenlerin konulara yaklaşımı ve tutumu belirlediği kitap, pedagojik olarak da bir hayli zayıftır.

\section{Sonuç}

Millî bir devlet olarak kurulan Türkiye Cumhuriyeti Devleti, doğası gereği, pek çok düzenlemede bulunmuş ve yenilik yapmıştır. Devletin ideallerine ve beklentilerine göre düzenlenen eğitim ve öğretim, yeni kuşaklar yetiştirmeyi ve bu kuşaklarda Cumhuriyet değerlerinin bilince çıkarılmasını 
hedeflemiştir. Millî devletin kültürel sacayağını oluşturan dil, edebiyat ve tarih, eğitim ve öğretime ilişkin düzenlemelerde temsil alanı olarak öne çıkmıştır. 1924'te hazırlanan müfredat programında, diğer derslerle birlikte, Türkçe ve Edebiyat derslerinin de çerçevesi ve nasıl işleneceği belirlenmiştir. Türkçe ve Edebiyat dersinin müfredat programını hazırlayanlar arasında bulunan Ali Canip, bu çerçeve doğrultusunda ilk “Edebiyat” ders kitabını da yazmış ve bu kitap, 1924'te Maarif Vekâleti tarafından yayımlanmıştır.

Lise mezunu sayılabilmek ve üniversiteye giriş hakkı kazanabilmek için 1926-1935 yılları arasında ölçme ve değerlendirmede uygulanan "bakalorya" modeli, 1930'ların ilk yarısında sınava hazırıkta kullanıımak üzere yazılan yardımcı kitapların yayımlanmasını hazırlamıştır. 1933-1935 yılları arasında, yayımlanan üç edebiyat bakalorya kitabı, lisenin üç sınıfında görülen Edebiyat dersinin içeriği gözetilerek düzenlenmiştir. Bununla birlikte, her bir kitap; konulara yaklaşım, bilginin değerlendirilmesi, anlatım ve anlatım tonu yönünden farklılıklar göstermektedir.

Muvaffak Hüsnü (Benderli)'nin edebiyat ve edebiyat tarihi kitaplarından aldığı notlarla oluşturduğu Edebiyat Bakalorya Elkitabı adlı çalışması, Ali Canip'in Edebiyat kitabındaki ideolojik yaklaşımı yansıtır. Basmakalıp yargılarda bulunan yazar, oluşturulmaya çalışılan edebiyat kanonunu bu kitabıyla benimser ve yayar. Konuların anlatımında ve ifadedeki tonda da nesnel tutumu değil öznel tutumu belirginleştirir. 1931'de Tanzimat'a Kadar Muhtasar Türk Edebiyatı Tarihi ve Nümuneleri adlı bir eser de çıkarmış olan Sadeddin Nüzhet Ergun, Edebiyat ve Edebiyat Tarihi Özü adlı kitabında, ideolojik yaklaşımdan uzak durur ve nesnelliğiyle rasyonel bir tutum sergiler. Yazar, yargılarında, analitiktir ve tarihselliği gözetir. Yusuf Ziya (Ortaç), Edebiyat Bakalorya Kitabı adlı çalışmasında, ideolojiyi içselleştirmiş bir dil ve ton kullanır; basmakalıp ve fevri yargılarda bulunur. Öznel yaklaşımla edebiyat öğretimini gölgeleyen yazar, konu nesnesini özcü bir tutumla değerlendirir. Söz konusu üç edebiyat bakalorya kitabı, hem bir ders için hazırlanan ilk elkitabı hem de ilk sınava hazırlık kitabı olmasıyla tarihsel bir önem taşımaktadır. Ayrıca bu kitaplar, dönemin ruhunu yansıtmaları bakımından dikkat çekmekte ve edebiyat öğretiminde nasıl bir yol izleneceğini göstermeleriyle de örnek oluşturmaktadır.

\section{Kaynaklar}

Ali Canip (1340). Edebiyat. İstanbul: Matbaa-i Âmire.

Ali Canip (1929). Edebiyat. İstanbul: Maarif Vekâleti Yayınları.

Akyüz, Y. (2010). Türk Eğitim Tarihi M.Ö. 1000-M.S. 2010. Ankara: Pegem Akademi Yayınları.

Benderli, M. H. (1937). Edebiyat ve Edebiyat Tarihi El Kitabı. İstanbul: Cumhuriyet Kitaphanesi.

Sadeddin Nüzhet (1931). Tanzimat'a Kadar Muhtasar Türk Edebiyatı Tarihi ve Nümuneleri. İstanbul: Semih Lütfü Kitabevi.

Ergun, S. N. (1935). Edebiyat ve Edebiyat Tarihi Özü. İstanbul: İnkılâb Kitabhanesi.

Göğüş, B. (1970). Anadili Olarak Türkçenin Öğretimine Bir Bakış. Türk Dili Araştırmalar Yıllığı Belleten, 124-154. 
Örik, N. S. (1935). “Edebiyat Tarihi Özü”. Varlık dergisi, 43 (4), 327-328.

[Kurul] (1340a). Lise Müfredat Programları Esbâb-ı Mûcibe Lâyihası. İstanbul: Matbaa-i Âmire.

[Kurul] (1340b). Lise Birinci Devre Müfredat Programları. İstanbul: Matbaa-i Âmire.

[Kurul] (1340c). Liselerin Ikinci Devre Müfredat Programları. İstanbul: Matbaa-i Âmire.

[Kurul] (1927). 1340 Tarihli Ortamektep ve Lise Müfredat Programlarına Zeyl. İstanbul: Devlet Matbaası.

Muvaffak Hüsnü (1933). Edebiyat Bakalorya Elkitabı. İstanbul: Bürhaneddin Matbaası.

Ogur, E. (2009). Ali Canip Yöntem'in Eğitim ve Edebiyat Eğitimi Hakkındaki Düşünceleri. Uludağ Üniversitesi Eğitim

Fakültesi Dergisi, XXII (2), 397-415.

Yusuf Ziya (1935). Edebiyat Bakalorya Kitabı. İstanbul: Kanaat Kütüphanesi.

Yücel, H. A. (1938, 29 Birinci Teşrin). Türk Maarifi. Cumhuriyet gazetesi. s. 15.

\section{Extended Abstract}

State of the Republic of Turkey which was established as a national state inherently has made many regulations and innovations. Founded on the ideals and the expectations of the state, education and teaching have aimed at raising new generations and achieving awareness of Republic values. Language, literature and history, which constitute the cultural trivet of the national state, have come into prominence as representations of education and teaching regulations.

Language and literary education in the Republican Era were shaped within the frame of 'the Law on Unification of Education' enacted on March 3, 1924. With this law, education and teaching took on a secular nature and educational uniformity was secured. The curriculum for secondary education institutions was regulated in 1924, after this law. In the High School Curriculum Programs published in 1924, the content of Turkish and literature courses was determined jointly. The secondary education, collected under the name of high school, covered secondary school for the first three years and the next three years were high school. In 1924, the Secondary Curriculum of High School described what subjects would be taught in Literature courses in detail. The offered subjects accordingly were 'Turkish Language and Literature' in the first year of high school, 'The History of Turkish Literature' in the second year and 'Turkish Literature within Western Literature' in the third year.

The process described above shows that Turkish and literary education in the Early Republican Era not only constituted some courses but also some areas representing the expectation of the Republican regime. The aim was to raise the Republican and secular awareness and hence the curriculum, textbooks, other supplementary books and teaching methods were all prepared in accordance with this aim. The exams functioned as a means of assessment and evaluation as well as a reflection of whether this awareness was acquired.

In order to be regarded as a high school graduate and in order to gain admission to the university, a 'baccalaureate' model was applied to assessment and evaluation between the years 1926 and 1935. In the first half of the 1930s, baccalaureate books were prepared for Chemistry, Geography, History and Literature courses. These were distinguished as the publications are reinforcing the regime's expectations. Three literary baccalaureate books were published between the years 1933 and 1935 . The literary baccalaureate books were organized in accordance with the content of the Literature course for the third year of high school. Also, each book differed from the other in terms of method, approach, narration and tone of expression.

Muvaffak Hüsnü Benderli made his study called Edebiyat Bakalorya Elkitabı (The Handbook of Literary Baccalaureate) with notes from literature and literary history books. Benderli has some subjective inferences and this subjectivity can also be seen in his narrative. By highlighting the ethnic origin of some poets and authors, he enhances his interferences. Through this book of him, Benderli embraces and propagates the official literature canon that the Republic tried to construct.

Sadeddin Nüzhet Ergun published his literary baccalaureate book called Edebiyat ve Edebiyat Tarihi Özü (Literature and The Essentials of Literary History). Ergun stands out from ideological approach and exhibits a rational attitude with his objectivity. He states that the Ottoman and Sufi literatures are the literatures of 'eximious ones', but he expresses this with an objective attitude, not with an ideological emphasis. He also does not use an ideological filter while giving information about these literatures. The author infers analytically and regards historicity.

In his Edebiyat Bakalorya Kitabı (Literary Baccalaureate Book), Yusuf Ziya Ortaç embraces the attitude and tone of expression of national literary canon. He presents 'the language of Ottoman Turkish' as a 'make- 
up/artificial language', externalizes the aruz prosody and features syllabic meter. Ortaç exaggerates the poets and authors whom the canon adopts and in the same manner he externalizes whom the canon exempts. Influenced by the acceptance of nationalism, he draws attention to the private life and ethnic origin of poets and authors in some of his inferences.

The three literary baccalaureate books in question are of historical importance as they are both the first handbooks prepared for a course and the first books to study for the exam. Also, these books attract attention as they reflect the spirit of the period and they set a good example of how to teach literature. 